\title{
Ergonomi Duduk yang Benar untuk Mencengah Terjadinya Low Back Pain (LBP) di Kelurahan Mayang Mangurai Kota Jambi
}

\author{
Putra Hadi $^{1}$, Wanti Hasmar ${ }^{2}$ \\ ${ }^{1,2}$ Program Studi D III Fisioterapi, STIKes Baiturrahim Jambi ${ }^{1}$ \\ e-mail:putrahadi915@gmail.com
}

Submitted : 09/09/2021

Accepted: 22/10/2021

Published: 19/11/2021

\begin{abstract}
One of the musculoskeletal disorders that often occurs due to incorrect ergonomics is low back pain. Low back pain (LBP) is a pain syndrome that occurs in the lower back region which is the result of various causes including abnormalities of the spine or spine from birth, trauma, tissue changes, and the influence of gravity. Community service activities will be held in April-June 2021 with discussion methods and delivering materials and leaflets related to the introduction of ergonomics in the correct sitting position in order to reduce the impact of low back pain. This Community Service (PKM) aims to be used as a source of knowledge for recitation mothers at the Nurul Al-Ikhlas mosque. The results of the evaluation through the question and answer were that the study mothers had understood the introduction of ergonomic sitting to prevent LBP
\end{abstract}

Keywords : ergonomic, low back pain

\begin{abstract}
Abstrak
Salah satu gangguan muskuloskelatal yang sering terjadi akibat ergonomic yang salah adalah low back pain. Low back pain (LBP) adalah suatu sindroma nyeri yang terjadi pada regio punggung bagian bawah yang merupakan akibat dari berbagai sebab diantaranya kelainan tulang punggung atau spine sejak lahir, trauma, perubbahan jaringan, dan pengaruh gaya berat. Kegiatan Pengabdian masyarakat dilaksanakan pada bulan April-Juni 2021 dengan metode diskusi dan menyampaikan materi serta leaflet terkait pengenalan ergonomi posisi duduk yang benar agar dapat mengurangi dampak terjadinya nyeri pinggang bawah. Pengabdian kepada Masyarakat (PKM) ini bertujuan untuk dapat dijadikan sebagai sumber pengetahuan bagi ibu-ibu pengajian di masjid Nurul Al-Ikhlas. Hasil evaluasi melalui tanya jawab tersebut adalah ibu-ibu pengajian telah memahami pengenalan ergonomic duduk untuk mencegah LBP
\end{abstract}

Kata kunci : ergonomi. nyeri punggung bawah

\section{PENDAHULUAN}

Menurut Undang-undang Kesehatan No. 36 Tahun 2009. Kesehatan adalah keadaan sehat, baik secara fisik, mental, spiritual maupun sosial yang memungkinkan setiap orang untuk hidup produktif secara sosial dan ekonomis. Upaya kesehatan adalah setiap kegiatan atau serangkaian kegiatan yang dilakukan secara terpadu, terintegrasi dan berkesinambungan untuk memelihara dan meningkatkan derajat kesehatan masyarakat dalam bentuk pencegahan penyakit, peningkatan kesehatan, pengobatan penyakit, serta pemulihan kesehatan oleh pemerintah atau masyarakat.
Upaya mewujudkan pelayanan kesehatan dapat dilihat dari empat aspek, yaitu pelayanan kesehatan promotif adalah suatu kegiatan atau serangkaian kegiatan pelayanan kesehatan yang lebih mengutamakan kegiatan yang bersifat promosi kesehatan, pelayanan kesehatan preventif adalah suatu kegiatan atau serangkaian kegiatan pencegahan terhadap suatu masalah kesehatan atau penyakit, pelayanan kuratif adalah suatu kegiatan atau serangkaian kegiatan pengobatan yang ditujukan untuk penyembuhan penyakit, pengurangan penderita akibat penyakit, mengendalikan kecacatan agar kualitas penderita dapat terjaga seoptimal mungkin, 
dan pelayanan kesehatan rehabilitatif adalah suatu kegiatan atau serangkaian kegiatan untuk mengembalikan bekas penderita ke dalam masyarakat sehingga dapat berfungsi lagi sebagai anggota masyarakat (Undangundang kesehatan No. 36 Tahun 2009 pasal 1).

Ergonomi berasal dari bahasa Yunani, ergon yang artinya kerja dan nomos yang artinya peraturan atau hukum, sehingga secara harfiah dapat diartikan sebagai peraturan tentang bagaimana melakukan kerja, termasuk sikap kerja. Seirama dengan perkembangan kesehatan kerja ini maka hal-hal yang mengatur antara manusia sebagai tenaga kerja dan peralatan kerja atau mesin juga berkembang menjadi cabang ilmu tersendiri (Notoatmodjo, 2010).

Low Back Pain (LBP) atau nyeri punggung bawah dapat didefinisikan sebagai rasa nyeri dan ketidaknyamanan di area punggung bawah atau bawah tulang rusuk dan di atas lipatan gluteal. Pada beberapa kasus LBP gejalanya sesuai dengan diagnosis patologisnya dengan ketepatan yang tinggi, namun sebagian besar kasus, diagnosis tidak pasti dan berlangsung lama. LBP dapat diklasifikasikan menjadi spesifik yaitu ketika penyebab nyeri diketahui, sedangkan non-spesifik, nyeri didefinisikan sebagai nyeri tanpa sebab yang jelas atau mekanisme cedera. LBP juga dapat diklasifikasikan menurut durasi gejala, yaitu akut (sampai enam minggu), subakut (6 sampai 12 minggu), dan kronis(tiga bulan atau lebih) (Bauer et al, 2017).

Low Back Pain (LBP) merupakan keluhan yang sering dijumpai dan umum dalam masyarakat. Hampir setiap orang pernah merasakan LBP dalam hidupnya. LBP termasuk salah satu gangguan muskulo-skeletal yang sering terjadi dan menyebabkan penurunan produktivitas kerja dan disabilitas. LBP memiliki dampak besar terhadap individu, keluarga, masyarakat dan bisnis di seluruh dunia. (Sari, 2015).

Menurut Rinta (2013) dari beberapa laporan dan hasil penelitian yang pernah dilakukan menyebutkan bahwa penyakit akibat kerja khususnya low back pain (LBP) yang disebut juga nyeri punggung bawah (NPB) merupakan penyakit yang paling banyak dialami pekerja, dimana kejadian ini tidak mengenal perbedaan umur, jenis kelamin, pekerjaan, status sosial, maupun tingkat pendidikan/ pengetahuan, semua dapat terkena. Lebih dari $70 \%$ manusia dalam kehidupannya pernah mengalami NPB, dengan rata-rata puncak kejadian berusia 35-55 tahun. Di Amerika dan Australia low back pain merupakan satu darisepuluh keluhan utama dan dilaporkan prevalensi nyeri punggung bawah berkisardi antara $26,4 \%-79,2 \%$ (Johannes, 2010).

Pada tahun 2007 di Belanda, nyeri punggung mengakibatkan kerugian sebesar $€ 3534$ juta pound sterling, dan menyebabkan kehilangan waktu kerja sebanyak 6.057.140 hari. Pada tahun 1997 LBP dilaporkan berdampak pada perindustrian di Amerika sebesar \$171 juta. Kebanyakan kejadian LBP dikaitkan dengan jenis pekerjaan seperti mengangkat (Halimah, 2011). Berdasarkan penelitian Picavet dan Schouten (2001) dalam Halimah (2011) yang dilakukan pada 8.000 orang sampel yang berumur 25 tahun ke atas di Belanda dengan desain penelitian kohort, hampir tiga perempat $(74,5 \%)$ penduduk Belanda yang berumur 25 tahun ke atas dilaporkan menderita nyeri muskoskeletal dalam 12 bulan terakhir dengan prevalensi 53,9\%, dan yang menderita LBP dalam 3 bulan terakhir dengan prevalensi $44,4 \%$. Ranking dari bagian-bagian nyeri yang paling banyak dilaporkan secara berurutan adalah: 1) punggung bawah $(22,2 \%) ; 2)$ bahu $(15,1 \%)$; 3) leher $(14,3 \%)$; 4) lutut $(11,7 \%)$; 5) pergelangan/tangan $(9,3 \%) ; 6)$ punggung atas $(7,4 \%) ; 7)$ pinggul $(6,2 \%) ; 8)$ siku 
$(5,3 \%) ; 9)$ kaki $(5,0 \%) ; 10)$ pergelangan kaki $(3,5 \%)$. Berdasarkan penelitian yang dilakukan Community Oriented Program for Controle of Rheumatic Disease (COPORD) bahwa di Indonesia angka kejadian nyeri punggung menunjukan 18,2 $\%$ pada laki laki dan $13,6 \%$ pada wanita. National Safety Council melaporkan penyakit akibat kerja yang frekuensi kejadian paling tinggi adalah sakit/nyeri pada punggung, yaitu $22 \%$ dari 1.700 .000 kasus (Rinta, 2013).

Hasil penelitian yangdilakukan oleh Persatuan Dokter Saraf Seluruh Indonesia (PERDOSSI) pada pasien diPoliklinik Neurologi Rumah Sakit Cipto Mangunkusumo (RSCM) pada tahun2002 menemukan prevalensi penderita nyeri punggung bawah sebanyak 15,6\%.Angka ini berada pada urutan kedua tertinggi sesudah sefalgia dan migren yangmencapai $34,8 \%$. Hasil penelitian secara nasional yang juga dilakukan di 14 kota di Indonesia oleh kelompok studi nyeri PERDOSSI tahun 2002 ditemukan $18,1 \%$ penderita nyeri punggung bawah (Johannes, 2010).

Fisioterapi merupakan bentuk pelayanan kesehatan yang ditujukan kepada individu atau kelompok untuk mengembangkan, memelihara, dan memulihkan gerak dan fungsi tubuh sepanjang rentang kehidupan dengan menggunakan penanganan secara manual, peningkatan gerak, peralatan (fisik, elektroterapiutis, dan mekanis), pelatihan fungsi, dan komunikasi (MenKes , 2013). Fisioterapi mempunyai peranan yang sangat penting dalam ergonomi posisi duduk yang benar dengan analisis anatomi, biomekanika dan kinesiologi, sehingga dapat mengurangi terjadinya LBP.

Metode yang digunakan adalah penjelasan kepada ibu-ibu pengajian masjid Nurul Al-Ikhlas menggunakan media leaflet mengenai pengenalam ergonomi posisi duduk yang benar untuk mengurangi dampak terjadinya LBP kemudian ibu-ibu pengajian masjid Nurul Al-Ikhlas memberikan respon. Hasil diskusi yang diharapkan pada pelaksanaan pengabdian masyarakat ini adalah agar para ibu-ibu pengajian Masjid Nurul Al Ikhlas mengetahui ergonomi posisi duduk yang benar sehingga bisa mengurangi dampak terjadinya low back pain. Kegiatan pengabdian masyarakat ini diawali dengan survei untuk mengetahui bagaimana tingkat pengetahuan ibu-ibu pengajian masjid Nurul Al-Ikhlas.

\section{TARGET DAN LUARAN}

Kontribusi mendasar dari kegiatan ini adalah peningkatan kemampuan masyarakat dalam memahami dan menerapkan ergonomi posisi duduk yang benar dalam beraktivitas secara mandiri dan sesuai dengan kebutuhan kesehatan masyarakat di kelurahan mayang mangurai kota jambi.

Target Luaran dari kegiatan ini adalah mengenalkan ergonomi posisi duduk yang benar untuk mengurangi LBP.

\section{METODE PELAKSANAAN}

Kegiatan pengabdian masyarakat ini dilaksanakan pada ibu-ibu pengajian di masjid Nurul Al-Ikhlas, Sungai Sawang, Mayang Arizona, Kecamatan Alam Barajo pada April-Juni 2021 dengan sasaran Ibuibu pengajian di masjid Nurul Al-Ikhlas. Kegiatan Pengabdian Kepada Masyarakat (PKM) ini bertujuan untuk mengenalkan ergonomi posisi duduk yang benar agar dapat mengurangi dampak terjadinya low back pain (LBP) pada ibu-ibu pengajian di Masjid Nurul Al-Ikhlas.

Kegiatan pengabdian masyarakat ini diharapkan dapat meningkatnya pengetahuan ibu-ibu pengajian dan dapat menerapkannya di rumah.

1. Pelaksanaan Kegiatan

Tahap pelaksanaan kegiatan pengabdian kepada masyarakat ini adalah sebagai berikut:

a. Persiapan: Tahapan ini merupakan tahapan awal dari pelaksanan 
Pengabdian Masyarakat yaitu berupa perizinan dari ketua pengajian di masjid Nurul AlIkhlas. Setelah mendapat izin, selanjutnya Tim Pengabdian Masyarakat melaksanakan sedikit diskusi terkait Pengabdian Masyarakat yang akan dilaksanakan.

b. Selanjutnya perancangan Materi dan pembuatan poster bergambar mengenai pengenalan ergonomic duduk untuk mencegah LBP. Sebelum menyampaikan leaflet, TIM Pengabdian Masyarakat menyampaikan materi terkait dengan ergonomi posisi duduk yang benar agar dapat mengurangi dampak terjadinya low back pain (lbp). Selanjutnya memberikan leaflet dan menjelaskan leaflet tersebut serta berdiskusi dengan ibu-ibu pengajian mengenai ergonomi posisi duduk yang benar agar dapat mengurangi dampak terjadinya low back pain (LBP).

2. Pelaksanaan

Pada tahap ini mulai dilakukan sosialisasi dan edukasi terkait dengan pengenalan ergonomi posisi duduk yang benar agar dapat mengurangi dampak terjadinya low back pain (lbp) dengan leaflet.

3. Monitoring dan Evaluasi

Monitoring dan evaluasi (Monev) dilakukan secara langsung kepada sasaran. Cakupan Monev dalam kegiatan ini meliputi monev perencanaan dan pelaksanaan dan evaluasi hasil.

Monitoring dan evaluasi dilakukan dengan diskusi Tanya jawab. Evaluasi ini bertujuan untuk mengetahui sejauh mana respon dan peningkatan pemahaman serta pengetahuan masyarakat terkait Pengabdian Masyarakat yang sudah dilaksanakan. Cakupan monev dalam kegiatan ini meliputi empat aspek, yaitu sebagai berikut .

Cakupan Monev dalam kegiatan ini meliputi monev perencanaan dan pelaksanaan dan evaluasi hasil. Hasil evaluasi baik melalui tanya jawab adalah rata-rata ibu-ibu pengajian masjid Nurul Al-Ikhlas mengetahui dan dapat mempraktekkan kegiatan pengenalan ergonomi posisi duduk ang benar untuk mengurangi dampak terjadinya low back pain

\section{HASIL DAN PEMBAHASAN}

Edukasi atau yang sering juga disebut Pendidikan merupakan segala upaya yang direncanakan untuk mempengaruhi orang lain baik individu, kelompok maupun mayarakat sehingga melakukan apa yang diharapkan oleh pelaku Pendidikan. Dalam kamus besar Bahasa Indonesia (KBBI) Pendidikan berasal dari kata dasar didik (mendidik), yaitu memelihara dan memberi latihan (ajaran pimpinan) mengenai akhlak dan kecerdasan pikiran.

Kegiatan pengabdian masyarakat ini dilaksanakan pada ibu-ibu pengajian di masjid Nurul Al-Ikhlas, Sungai Sawang, Mayang Arizona, Kecamatan Alam Barajo pada tanggal 27 Juni 2021 dengan sasaran Ibu-ibu pengajian di masjid Nurul Al-Ikhlas. Kegiatan Pengabdian Kepada Masyarakat (PKM) ini bertujuan untuk mengenalkan ergonomi posisi duduk yang benar agar dapat mengurangi dampak terjadinya low back pain (lbp) pada ibu-ibu pengajian di Masjid Nurul Al-Ikhlas. Pengabdian masyarakat ini dilakukan oleh 3 orang orang tim dosen dari program studi D-III Fisioterapi dan dibantu oleh Mahasiswa/mahasiswi Program Studi D3 Fisioterapi STIKes Baiturrahim Jambi, dihadiri oleh ibu-ibu pengajian Masjid Nurul Al-Ikhlas.

Adapun Kegiatan yang telah dilakukan adalah menyampaikan materi dan leaflet mengenai pengenalan 
ergonomi duduk yang benar untuk mengurangi dampak terjadinya low back pain.

Posisi kerja yang berbeda dalam beraktivitas, menyebabkan perbedaan jumlah otot yang digunakan dan tenaga yang diperlukan. Bekerja dengan posisi duduk dan relaksasi melibatkan intensitas kontraksi otot yang rendah dari pada bekerja dengan berdiri. Dalam bekerja, posisi fisiologis sangat penting agar tidak banyak melibatkan intensitas kontraksi otot, tidak mudah lelah, dan produktivitas kerja dapat meningkat. Sikap kerja tidak alamiah menyebabkan bagian-bagian tubuh bergerak menjauhi posisi alamiah, seperti pergerakan tangan terangkat, punggung terlalu bungkuk, kepala terangkat, dan sebagainya. Semakin jauh posisi bagian tubuh dari pusat gravitasi tubuh, maka semakin tinggi pula resiko terjadinya keluhan otot skeletal.

Nyeri punggang bawah non-spesifik terjadi karena biomekanik vertebra lumbal akibat perubahan titik berat badan dengan kompensasi perubahan posisi tubuh dan akan menimbulkan nyeri. Ketegangan (strain) otot dan keregangan (sprain) ligamentum tulang belakang merupakan salah satu penyebab utama nyeri punggung bawah atau low back pain. Keluhan otot skeletal pada umumnya muncul karena kontraksi otot berlebih akibat dari pemberian beban kerja yang terlalu berat dengan durasi pembebanan yang panjang. Apabila kontraksi otot terus-menerus dapat menyebabkan peredaran darah ke otot berkurang, hal ini menyebabkan suplai oksigen ke otot menurun. Proses metabolism karbohidrat terhambat dan sebagai akibatnya terjadi penimbunan asam laktat yang menyebabkan timbulnya rasa lelah dan nyeri di otot (Wardaningsih, 2010).

Repetitif yang berlebihan, melakukannya secara terus menerus, dan dengan posisi duduk yang monoton dapat menimbulkan perubahan garis lengkung atau kurva tulang belakang pada seseorang sehingga terjadi muncul keluhan nyeri pada bagian tertentu.

Kondisi ini bisa dicegah dengan memperhatikan aspek ergonomi dalam bekerja. Ergonomi berasal dari bahasa Yunani, ergon yang artinya kerja dan nomos yang artinya peraturan atau hukum, sehingga secara harfiah dapat diartikan sebagai peraturan tentang bagaimana melakukan kerja, termasuk sikap kerja. Seirama dengan perkembangan kesehatan kerja ini maka hal-hal yang mengatur antara manusia sebagai tenaga kerja dan peralatan kerja atau mesin juga berkembang menjadi cabang ilmu tersendiri (Notoatmodjo, 2010).

Posisi duduk tegak akan membuat peningkatan tekanan pada bantalan saraf sebesar $140 \%$ dan duduk dengan posisi tubuh membungkuk ke arah depan akan menyebabkan terjadinya peningkatan tekanan sebesar 190\%. Hal ini tentu akan membahayakan bantalan saraf yang menopang punggung bagian belakang.

Posisi duduk pada otot rangka (musculoskeletal) dan tulang belakang terutama pada pinggang harus dapat ditahan oleh sandaran kursi agar terhindar dari nyeri dan cepat lelah. Pada posisi duduk, tekanan tulang belakang akan meningkat dibanding berdiri atau berbaring, jika posisi duduk tidak benar. Tekanan posisi tidak duduk $100 \%$, maka tekanan akan meningkat menjadi $140 \%$ bila sikap duduk tegang dan kaku, dan tekanan akan meningkat menjadi 190\% apabila saat duduk dilakukan membungkuk kedepan. Oleh karena itu perlu sikap duduk yang benar dapat relaksasi (tidak statis) (Yeni, 2010).

Duduk terbagi menjadi 3 posisi, posisi pertama adalah membungkuk dimana posisi tubuh condong ke depan dengan sudut kemiringan 70 derajat, posisi duduk tegak (90 derajat) dan duduk 
santai dengan postur kemiringan 135 derajat. Posisi duduk lurus kebelakang bukanlah posisi duduk yang optimal untuk tulang belakang. Penelitian menunjukan bahwa duduk dengan postur tubuh 135 derajat, dimana pinggul lebih tinggi dari lutut, membuat berkurangnya tegangan pada lumbar spine dan lebih menstimulasi keadaan relaksasi dari supine spine. Posisi yang paling buruk untuk tulang belakang adalah posisi bungkuk (posisi duduk dengan kemiringan condong kedepan sebesar 70 derajat), diikuti dengan duduk pada posisi tegak 90 derajat (Wendling, 2007).

Piringan tulang belakang saat timbunan beban berat badan terpusat semuanya pada tulang belakang seehingga piringan sendi ke luar dari tempatnya. Pergerakan sendi ini ditentukan pada posisi duduk 90 derajat dari kursi, sementara menyandar bisa mengurangi ketegangan piringan sendi dan mebuat tendon dan otot jadi relaks. Sementara posisi membungkuk menyebabkan pergerakan tinggi tulang belakang bagian bawah. Posisi menyandar (135 derajat) adalah posisi terbaik karena posisi tersebut tidak

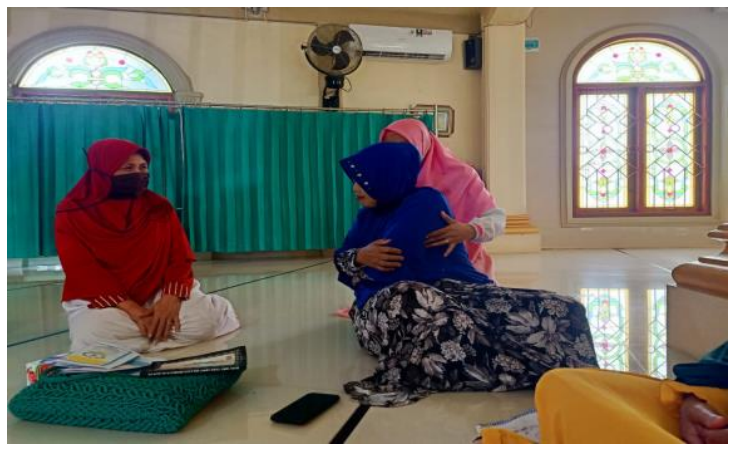

Gambar 1. Stimulasi Exercise menyebabkan tekanan pada ligamentum dan otot-otot tetap berada dalam posisi baik di daerah punggung (Rosadi, 2012).

Menurut Tarwaka (92013), untuk mencegah terjadinya Nyeri Punggang Bawah pada saat duduk, ada beberapa hal yang harus dilakukan selama duduk. Sebaiknya duduk dengan punggung lurus dan bahu berada di belakang dengan bokong menyentuh kursi. Apabila tidak terdapat pendukung lumbal, dapat dilakukan dengan cara duduk di ujung kursi dan membungkuk sempurna. Tubuh ditegakkan dan lengkungan tubuh (kurva) dibuat sebisa mungkin, kemudian tahan beberapa detik. Setelah itu posisi tersebut dilepaskan secara ringan.

Ketika duduk, lutut ditekukkan pada sudut yang benar. Lutut tetap dijaga setinggi atau lebih rendah dari pinggul. Tungkai sebaiknya tidak menyilang. Kaki tetap dijaga rata dengan lantai. Hindari duduk dengan posisi yang sama lebih dari 30 menit. Siku dan lengan diistirahatkan pada kursi atau meja serta bahu dijaga agar tetap rileks. Bila berdiri dengan posisi duduk, berdiri dengan meluruskan kedua tungkai. Hindari membungkukkan badan ke depan dengan pinggang.

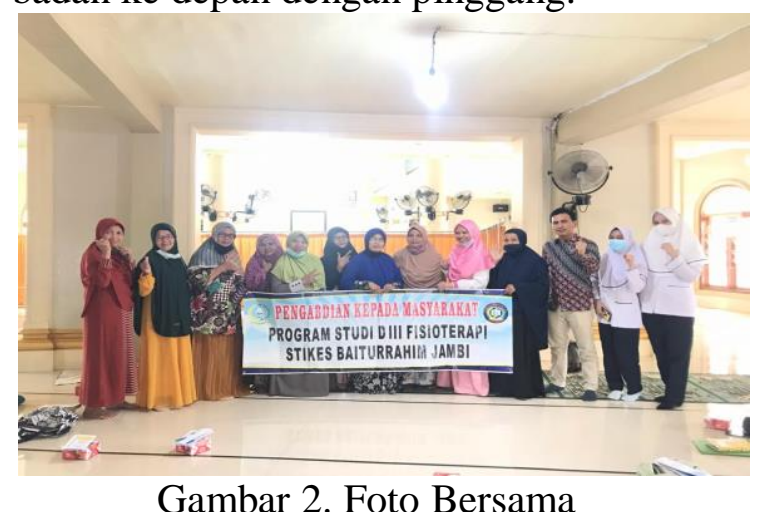

Gambar 2. Foto Bersama 


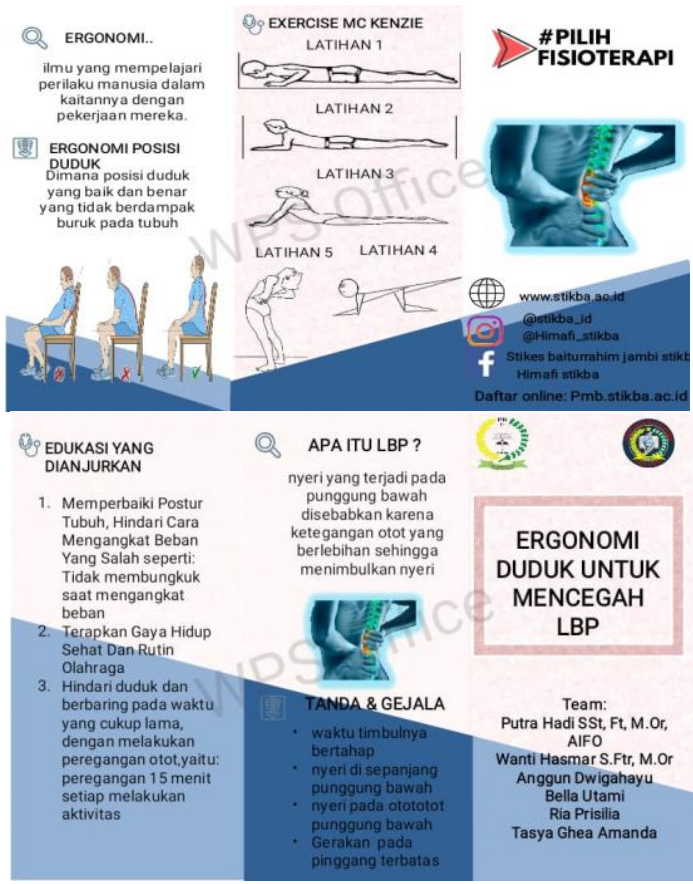

Gambar 3. Leaflet Kegiatan

\section{KESIMPULAN DAN SARAN}

1. Kesimpulan

Setelah tim melaksanakan kegiatan pengabdian masyarakat pada ibu-ibu pengajian di Masjid Nurul Al-Ikhlas, ibuibu tersebut dapat memahami dan menerapkan ergonomic duduk yang baik agar mencegah dampak terjadinya low back pain.

2. Saran

Hendaknya edukasi kegiatan pengenalan ergonomic posisi duduk untuk mengurangi dampak terjadinya low back pain memberikan pengetahuan pada ibu-ibu pengajian Masjid Nurul AlIkhlas dan dapat diterapkan serta dipraktekkan di rumah.

\section{UCAPAN TERIMAKASIH}

Tim Pengabdian mengucapkan terimakasih kepada STIKes Baiturrahim Jambi atas dukungan moril serta materil sehingga kegiatan ini dapat terlaksana dengan baik.

\section{DAFTAR PUSTAKA}

Bauer, C. M., Rast, F. M., Ernst, M. J., Meichtry, A., Kool, J., Rissanen, S. M., ... \& Kankaanpää, M. (2017). The effect of muscle fatigue and low back pain on lumbar movement variability and complexity. Journal of Electromyography and Kinesiology, 33, 94-102.

Johanes, 2010. Hubungan Antara Postur Tubuh dengan Terjadinya Nyeri Punggung Bawah pada Pasien Poliklinik Neurologi di RSUP H. Adam Malik Medan 2010, USU: Fakultas Kedokteran Universitas Sumatera Utara

Halimah. 2011. Karakteristik Penderita Nyeri Punggung Bawah (NPB) yang Rawat Inap di Rumah Sakit Umum Dr. Pirngadi Medan Tahun 2009-2010. Skripsi. Medan: USU

Natosba, Jum., Jaji. (2016). "Pengaruh Posisi Ergonomis Terhadap Kejadian Low Back Pain Pada Penenun Songket Di Kampung Bni 46". Jurnal Keperawatan Sriwijaya, 3(2) ISSN: 2355-5459

Perdani, P. 2010. Pengaruh Postur Dan Posisi Tubuh Terhadap Timbulnya Nyeri Punggung Bawah. Diakses pada tanggal 31 Juli 2021 di http://eprints.undip.ac.id/23653/

Paulsen, F, \& J. Waschke. 2010. Sobotta Atlas Anatomi Manusia Anatomi Umum dan Sistem Muskuloskeletal. 23th ed. Penerbit Buku Kedokteran EGC. Jakarta.

Pramana, I. G. B. T \& Adiatmika, I. P. G. 2020. Hubungan Posisi Dan Lama Duduk Dalam Menggunakan Laptop Terhadap Keluhan Low Back Pain Pada Mahasiswa Fakultas Kedokteran Universitas Udayana. Jurnal Medika Udayana. Diakses tanggal 31 Juli 2021 dari: https://ojs.unud.ac.id/index.php/eu $\mathrm{m} /$ article/view/64052 
Rinta. 2013. Pengaruh Back Exercise Terhadap Pengurangan Nyeri Punggung Bawah pada Petugas Instalasi Rekam Medik RSUP H.Adam Malik Medan Tahun 2013. Tesis. Medan: USU.

Rw, D. W. S \& Natalia. D. 2010. Nyeri Punggung Pada Operator Komputer Akibat Posisi Dan Lama Duduk. Journal Fakultas Kedokteran UNPAD. Diakses tanggal 31 Juli 2021 dari : http://journal.fk.unpad.ac.id/index.php/mkb/article/viewFil $\mathrm{e} / 23 / 24$

Rosadi, R. 2012. Hubungan kebiasaan duduk terhadap terjadinya skoliosis pada anak usia 11-13 tahun di sd pabelan kartasura Surakarta. Skripsi Universitas Muhamadiyah Surakarta, 2012:1-8.

Sutjana, I. D. P. 2006. Hambatan dalam penerapan K3 dan Ergonomi di Perusahaan. Seminar Ergonomi dan K3. Diakses tanggal 31 Juli 2021 dari:https://ojs.unud.ac.id/index.php /ijbs/article/download/3717/2738

Sari, N. P., Mogi, T. I. \& Angliadi, E., 2015. Hubungan Lama Duduk Dengan Kejadian Nyeri Punggung Bawah Pada Operator Komputer Perusahaan Travel di Manado. Jurnal e-Clinic (eCl), 3(2), pp. 687694.

Tarwaka (2013).

"Dasar-Dasar Pengetahuan Ergonomi Dan Aplikasi Di Tempat Kerja",Surakarta.

Valachi, B. \& Valachi, K. 2003. Mechanisms Leading to musculoskeletal disorders in dentistry. The Journal Of American Dental Association. Diakses tanggal 31 Juli 2021 dari: https://jada.ada.org/article/S00028177(14)6511 6-3/fulltext
Wahyuni, L. G. A. S. N,. Winaya, I. M. N \& Primayant, I. D. A. I. D 2015. Sikap Duduk Ergonomis Mengurangi Nyeri Punggung Bawah Non Spesifik Pada Mahasiswa Program Studi Fisioterapi Fakultas Kedokteran Universitas Udayana. Majalah Ilmiah Fisioterapi Indonesia. Diakses pada tanggal 31 Juli 2021 dari:https://ojs.unud.ac.id/index.php /mifi/article/view/22061

Wahyuni., Nadi,L. G. A. S., Winaya., Niko,I. M.,Primayanti \& Dwi,I. D. A. I. 2016. Sikap Duduk Ergonomis Mengurangi Nyeri Punggung Bawah Non Spesifik Pada Mahasiswa Program Studi Fisioterapi Fakultas Kedokteran Universitas Udayana. Majalah Ilmiah Fisioterapi Indonesia. Diakses tanggal 31 Juli 2021 dari: https://ojs.unud.ac.id/index.php/mif i/article/view/22061

Wardaningsih, I. 2010. Pengaruh Sikap Kerja Duduk Pada Kursi Kerja Yang Tidak Ergonomis Terhadap Keluhan Otot-Otot Skeletal Bagi Pekerja Wanita Bagian Mesin Cucuk Di Pt. Iskandar Indah Printing Textile Surakarta. Skripsi. Universitas Sebelas Maret Surakarta.

Wendling, P. 2007. Forget about sitting up straight for best posture. Internal Medicine News, 2007;40(3):17.

Yeni, I. 2010. Gambaran sikap kerja dan keluhan kesehatan pada pekerja bagian produksi lateks pt. socfindo kebun karet aek pamienke rantau prapat tahun 2010. Skripsi Universitas Sumatera Utara. 2010:1-11. 